\title{
Should the susceptibility of cervid to coronaviruses be a matter of concern?
}

\section{Luciano Rodrigo Lopes ( $\nabla$ luciano.lopes@unifesp.br)}

Bioinformatics and Bio-Data Science Division - Health Informatics Department - Universidade Federal de São Paulo - UNIFESP, São Paulo, SP, Brazil https://orcid.org/0000-0002-0284-2821

\section{Short Report}

Keywords: SARS-CoV-2, COVID-19, coronavirus, white-tailed deer, wildlife

Posted Date: August 11th, 2021

DOl: https://doi.org/10.21203/rs.3.rs-798964/v1

License: (c) (i) This work is licensed under a Creative Commons Attribution 4.0 International License. Read Full License 


\section{Abstract}

The susceptibility of the white-tailed deer (Odocoileus virginianus) to SARS-CoV-2 has highlighted cervids as a new coronavirus reservoir. Cervids are known hosts for other coronaviruses (such as bovine-like coronavirus) and can harbour several pathogens that cause serious diseases in humans. Moreover, herds of cervids are largely distributed among wildlife and are in close contact with humans, who often hunt or rear these animals The increased incidence of severe acute coronavirus 2 (SARS-CoV-2) infections, especially in American countries, which serve as habitats for many cervids, including the white-tailed deer and other closely related species, can favour the transmission of coronaviruses from humans to wild animals. In this context, this letter briefly discusses some points that underscore the occurrence of SARSCoV-2 infections in cervids as a matter of concern.

\section{Full Text}

Since the beginning of the coronavirus disease (COVID-19) pandemic, the origin of the severe acute respiratory syndrome coronavirus 2 (SARS-CoV-2) has been attributed to bats (Zhou et al., 2020). These animals have been implicated as the primary hosts for this virus due to their central role in the origins of severe acute respiratory syndrome (SARS) and Middle East respiratory syndrome (MERS), the main coronavirus infections before COVID-19 (Zhou et al., 2020). Horseshoe bats and common pipistrelle bats are natural reservoirs for SARS-like-CoV and MERS-like-CoV, respectively (Lau et al., 2005; Woo et al., 2012). Moreover, bats harbour a series of zoonotic viruses, and several species of bats are widely distributed across the globe (Brook and Dobson, 2015; Wynne and Wang, 2013). Meanwhile, further studies have implicated other wild animals, such as civets, camels, and pangolins, as key members of the chains of transmission of coronaviruses to humans (Farag et al., 2015; Guan et al., 2003; Lopes et al., 2020). Currently, the detection of SARS-CoV-2 in companion animals, wild animals from zoos, and captive animals is alarming and raises concerns about other coronavirus-susceptible hosts (van Aart et al., 2021; Hamer et al., 2021; McAloose et al., 2020; do Vale et al., 2021).

In this context, recently, Palmer et al. (2021) reported that white-tailed deer (Odocoileus virginianus) are highly susceptible to SARS-CoV-2 infection, presenting efficient transmissibility (Palmer et al., 2021); these authors also showed that SARS-CoV-2-infected white-tailed deer presented subclinical infection with productive virus replication in the upper respiratory tract. Moreover, the infected animals shed infectious virus particles in their nasal secretions (Palmer et al., 2021). This means that the close contact between healthy white-tailed deer and infected animals may promote the transmission of SARS-CoV-2 through respiratory secretions.

Although the SARS-CoV-2 spillback from humans to wild cervids has not been reported previously, it is highly likely that cases of infection with this virus wildlife can emerge, leading to the establishment of cervids as potential reservoirs of coronavirus infection. Furthermore, previous studies had already reported that cervids can be infected with coronaviruses. Elk (Majhdi et al., 1997), sambar deer (Alekseev et al., 2008), sika deer (Yokoi et al., 2009), water deer (Kim et al., 2018), and white-tailed deer (Alekseev et 
al., 2008) are susceptible hosts for bovine-like coronavirus. In cattle, bovine coronavirus (BCoV) can cause diarrhoea and respiratory illness and, have been reported to be transmitted via faecal-oral or respiratory routes (Zhang et al.). In 1994, a bovine-like coronavirus was isolated from a child (Zhang et al., 1994). According to molecular evolutionary approaches used in previous study, bovine-like coronaviruses were estimated to share a recent common ancestor with human CoV-OC43 (HCoVOC43) (Hasoksuz et al., 2007), a coronavirus that causes common cold in humans (Birch et al., 2005). Additionally, cervids are also known to harbour pathogens that are transmitted to humans, such as rabies virus (Petersen et al., 2012), hepatitis E virus (Boadella et al., 2010; Medrano et al., 2012), Rift Valey fever virus (Wilson et al., 2018), Powassan virus (Nofchissey et al., 2013), West Nile virus (Miller et al., 2005), Toxoplasma sp. (Dubey et al., 2014), Leptospira spp. (Dubay et al., 2015), and Mycobacterium bovis (Lambert et al., 2016), which can cause serious diseases.

The susceptibility of cervids to SARS-CoV-2 has become a matter of concern due to the existence of a large number of cervid species and their wide distribution, which could enable the dissemination of a serious pathogen among wild animals. The circulation of SARS-CoV-2 in wildlife population may enable viral strains to evolve and adapt to new hosts, leading to transmission of a new pathogen to human populations (Banerjee et al., 2021). Although the transmission of viruses from humans to free-living wildlife requires a series of opportunities, the plausible transmission of SARS-CoV-2 to wildlife may occur indirectly via human faeces, considering that viral shedding of SARS-CoV-2 in stool samples occurs in a notable number of patients (Doorn et al., 2020). Furthermore, there are several opportunities for farmed and captive animals to be infected by SARS-CoV-2 (Fagre et al., 2020; Freuling et al., 2020; Kim et al., 2020). The large herding of some cervids, such as reindeer (Rangifer tarandus), white-tailed deer, roe deer (Capreolus sp.), and others, represents a favourable chance for these cervids to be involved in pathogen transmission to humans.

Cervids are distributed across Europe, Asia, and the Americas. They compose the family Cervidae (detailed in Table 1), which represents a diverse group into the order Artiodactyla, showing diversity in size, habitat, and behaviour (Klein, 1992). In addition to their high population densities, the larger body size of these animals can trigger a series of problems involving humans and cervids, such as injuries due to vehicle collisions and cervid-associated crop loss (McShea, 2012). Hunting and habitat destruction represent major threats for cervids (González and Duarte, 2020; McShea, 2012). They are hunted for their meat in most regions they inhabit. Although there are appropriate cervid-hunting regimens, some species of cervids are overhunted (Duarte et al., 2012a; McShea, 2012).

While some species of cervids such as red deer (Cervus elaphus), are more sensitive to the presence of humans, other species such as roe deer, can cope with human disturbance near settlements (Jiang et al., 2008). In this context, white-tailed deer appear to be adapted to human presence and activities. This species thrives and is found in a diverse range of habitats (Branan et al., 1985; Lagory, 1986; Laurent et al., 2021). However, although the population density of white-tailed deer remains stable in Canada and the USA, Latin American populations of this deer are declining due to overhunting and progressive habitat losses (Gallina, 2015). 
The habitat of white-tailed deer overlap with those of members from the genus Mazama. This genus includes cervids inhabit tropical forests. In Central America and Mexico, both the white-tailed deer and the Central American red brocket deer (Mazama temama) are found (Bello, 2015; Duarte et al., 2012b). In South America, white-tailed deer are restricted to the northern region and can be found in some countries together with the red brocket deer (Mazama americana) (Duarte et al., 2012b, 2012c). For instance, in Suriname, white-tailed deer inhabit coastal marshes, while red brocket deer inhabit the rainforest; the habitat ranges of these two species overlap slightly at the margins (Branan et al., 1985).

Although the preference of cervids for different habitats may impact their physiology and morphology, the close evolutionary relationship they share among themselves may reflect the genetic similarity between them. In this context, white-tailed deer share a close evolutionary relationship with red brocket deer (Figure 1). The Bayesian phylogenetic tree presented herein was constructed based on the mitochondrial cytochrome $b$ nucleotide sequences of 49 cervid species, and camels which served as the outgroup, using the Mr.Bayes v.3.2 software (Ronquist et al., 2012) and applying the general timereversible model (GTR) (Rodríguez et al., 1990), selected using using MEGA X software (DNA model selection) (Kumar et al., 2018). Phylogenetic analysis showed that the genus Mazama is not a monophyletic group. For instance, M. guazoupira, M. chunyi and $M$. nemorivaga are not nested in the same clade with red brocket deer. Moreover, the Central American red brocket deer (M. temama), red brocket deer ( $M$. americana), Brazilian dwarf brocket ( $M$. nana), and small red brocket (M. bororo) are close to the genus Odocoileus (Figure 1). Thus, considering that these cervids are closely related species, their potential susceptibility to SARS-CoV-2 must be taken into account.

All cervids from the gender Mazama, except the Central American red brocket deer, are closely related to white-tailed deer and are widely distributed in South America. The red brocket deer is one of the most abundant and widely distributed cervids in Neotropical forests (Varela et al., 2010). They inhabit almost all South American countries, except for Uruguay and Chile. Red brocket deer populations have been frequently threatened by commercial and subsistence hunting (Duarte et al., 2012c). Their meat is an important food source for people living close to Neotropical forests and is sold in urban and rural markets close to the Amazon (Varela et al., 2010). The red brocket deer is sympatric with two Brazilian endemic cervids: the Brazilian dwarf brocket and the small red brocket, which are threatened by hunters and predation by feral dogs (Duarte et al., 2012d, 2012e). These endemic species are found close to regions with a high density of human population.

The white-tailed deer and brocket deer are widely distributed across various countries in the American subcontinent; these represent some of the most prominent COVID-19-affected regions in the world. At the time of writing this article, the COVID-19 cases in the Americas accounted for 39\% of all COVID-19 cases worldwide. Moreover, although the American population represents only $13 \%$ of the global population, $48 \%$ of all COVID-19-associated deaths occurred in America. Thus, the close coexistence between SARSCoV-2-infected populations and cervids places these animals whithin the transmission chain of coronaviruses. 
In addition, during the pandemic, South American countries have relaxed their regulations and environmental policies, which has exacerbated deforestation (López-Feldman et al., 2020). Consequently, as human habitation ventures deeper into once-inaccessible tropical biomes, the potential contact with coronavirus-susceptible hosts can contribute to the transmission of these viruses to wildlife (Harvey, 2021). In this context, the progressive and continued environmental destruction and the conflicting coexistence between humans and wild animals may favour the exchange of pathogens. Thus, cervids may be involved in a pathogen-transmission chain because they are globally widespread, inhabit regions close to areas inhabited by humans, and can harbour a series of human pathogens, including coronaviruses. Therefore, molecular epidemiological surveillance must target cervids due to their potential to harbour SARS-CoV-2 or related coronaviruses, in order to take effective measures to control future outbreaks of coronavirus infections.

\section{Declarations}

\section{Funding}

Not applicable

\section{Availability of data and material}

All the data obtained from the NCBI GenBank databases included in this research study were associated with accession codes/numbers for research or reanalysis.

\section{Code availability}

Not applicable

\section{Ethics approval}

This research included secondary biological data with no possibility of individual identification. The Unifesp Research Ethics Committee was consulted and it was determined that this study did not require ethical approval.

\section{Conflict of interest statement}

The author state that there are no conflicts of interest to declare. 


\section{References}

van Aart AE, Velkers FC, Fischer EAJ, Broens EM, Egberink H, Zhao S, Engelsma M, Hakze-van der Honing RW, Harders F, de Rooij MMT, et al. (2021) SARS-CoV-2 infection in cats and dogs in infected mink farms. Transbound Emerg Dis. https://doi.org/10.1111/tbed.14173

Alekseev KP, Vlasova AN, Jung K, Hasoksuz M, Zhang X, Halpin R, Wang S, Ghedin E, Spiro D, and Saif LJ (2008) Bovine-Like Coronaviruses Isolated from Four Species of Captive Wild Ruminants Are Homologous to Bovine Coronaviruses, Based on Complete Genomic Sequences. J Virol 82: 1242212431. https://doi.org/10.1128/JVI.01586-08

Banerjee A, Mossman K, and Baker ML (2021) Zooanthroponotic potential of SARS-CoV-2 and implications of reintroduction into human populations. Cell Host Microbe 29: 160-164. https://doi.org/10.1016/j.chom.2021.01.004

Bello J, Reyna R, and Schipper J. (2015) IUCN Red List of Threatened Species: Mazama temama. IUCN Red List Threat. Species. https://dx.doi.org/10.2305/IUCN.UK.2016-2.RLTS.T136290A22164644.en

Birch CJ, Clothier HJ, Seccull A, Tran T, Catton MC, Lambert SB, Druce JD (2005) Human coronavirus OC43 causes influenza-like illness in residents and staff of aged-care facilities in Melbourne, Australia. Epidemiol Infect 133: 273-277. https://doi.org/10.1017/S0950268804003346

Boadella M, Casas M, Martín M, Vicente J, Segalés J, de la Fuente J, and Gortázar C (2010) Increasing contact with hepatitis E virus in red deer, Spain. Emerg Infect Dis 16: 1994-1996.

http://dx.doi.org/10.3201/eid1612.100557

Branan WV, Werkhoven MCM, and Marchinton RL (1985) Food Habits of Brocket and White-Tailed Deer in Suriname. J Wildl Manag 49: 972-976. https://doi.org/10.2307/3801381

Brook CE, and Dobson AP (2015) Bats as "special" reservoirs for emerging zoonotic pathogens. Trends Microbiol. 23: 172-180. https://doi.org/10.1016/j.tim.2014.12.004

van Doorn AS, Meijer B, Frampton CMA, Barclay ML, and de Boer NKH (2020). Systematic review with meta-analysis: SARS-CoV-2 stool testing and the potential for faecal-oral transmission. Aliment. Pharmacol. Ther. 52:1276-1288. https://doi.org/10.1111/apt.16036

Duarte JMB, Vogliotti A, Zanetti ES, Oliveira ML, Tiepolo LM, Rodrigues LF, Almeida LB, and Braga FG (2012a) Avaliação do risco de extinção do veado-campeiro Ozotoceros bezoarticus Linnaeus, 1758, no Brasil. Biodiversidade Bras - BioBrasil 20-32. https://doi.org/10.37002/biobrasil.v\%25vi\%25i.235

Duarte JMB, Vogliotti A, Zanetti ES, Oliveira ML, Tiepolo LM, Rodrigues LF, and Almeida LB (2012b) Avaliação do risco de extinção do veado-galheiro Odocoileus virginianus Zimmermann, 1780, no Brasil. Biodiversidade Bras - BioBrasil 15-19. 
Duarte JMB, Vogliotti A, Zanetti ES, Oliveira ML, Tiepolo LM, Rodrigues LF, Almeida LB (2012c) Avaliação do risco de extinção do veado-mateiro Mazama americana Erxleben, 1777, no Brasil. Biodiversidade Bras - BioBrasil 33-41. https://doi.org/10.37002/biobrasil.v\%25vi\%25i.236

Duarte JMB, Abril VV, Vogliotti A, Zanetti ES, Oliveira ML, Tiepolo LM, Rodrigues LF, and Almeida LB (2012d) Avaliação do risco de extinção do veado-cambuta Mazama nana Hensel, 1872, no Brasil. Biodiversidade Bras - BioBrasil 59-67.

Duarte JMB, Vogliotti A, Zanetti ES, Oliveira ML, Tiepolo LM, Rodrigues LF, and Almeida LB (2012e). Avaliação do risco de extinção do veado-mateiro-pequeno Mazamo bororo Duarte, 1996, no Brasil. Biodiversidade Bras - BioBrasil 42-49. https://doi.org/10.37002/biobrasil.v\%25vi\%25i.237

Dubay S, Jacques C, Golden N, Kern B, Mahoney K, Norton A, Patnayak D, and Deelen TV (2015) Environmental Factors Influencing White-Tailed Deer (Odocoileus virginianus) Exposure to Livestock Pathogens in Wisconsin. PLOS ONE 10: e0128827. https://doi.org/10.1371/journal.pone.0128827

Dubey JP, Dennis PM, Verma SK, Choudhary S, Ferreira LR, Oliveira S, Kwok OCH, Butler E, Carstensen M, and Su C (2014). Epidemiology of toxoplasmosis in white tailed deer (Odocoileus virginianus): occurrence, congenital transmission, correlates of infection, isolation, and genetic characterization of Toxoplasma gondii. Vet Parasitol 202: 270-275.

Fagre A, Lewis J, Eckley M, Zhan S, Rocha SM, Sexton NR, Burke B, Geiss B, Peersen O, Kading R, et al. (2020) SARS-CoV-2 infection, neuropathogenesis and transmission among deer mice: Implications for reverse zoonosis to New World rodents. BioRxiv 2020.08.07.241810.

https://doi.org/10.1101/2020.08.07.241810

Farag EABA, Reusken CBEM, Haagmans BL, Mohran KA, Raj VS, Pas SD, Voermans J, Smits SL, Godeke G-J, Al-Hajri MM, et al. (2015) High proportion of MERS-CoV shedding dromedaries at slaughterhouse with a potential epidemiological link to human cases, Qatar 2014. Infect Ecol Epidemiol 5: 10.3402/iee.v5.28305. https://doi.org/10.3402/iee.v5.28305

Freuling CM, Breithaupt A, Müller T, Sehl J, Balkema-Buschmann A, Rissmann M, Klein A, Wylezich C, Höper D, Wernike K, et al. (2020) Susceptibility of Raccoon Dogs for Experimental SARS-CoV-2 Infection. Emerg Infect Dis 26: 2982-2985. https://doi.org/10.3201/eid2612.203733

Gallina S, and Arevalo HL (2015) IUCN Red List of Threatened Species: Odocoileus virginianus. IUCN Red List Threat Species. https://dx.doi.org/10.2305/IUCN.UK.2016-2.RLTS.T42394A22162580.en

González S, and Duarte JMB (2020). Speciation, evolutionary history and conservation trends of neotropical deer. Mastozoologia Neotropical 37. http://dx.doi.org/10.31687/saremMN_SI.20.27.1.05

Guan Y, Zheng BJ, He YQ, Liu XL, Zhuang ZX, Cheung CL, Luo SW, Li PH, Zhang LJ, Guan YJ, et al. (2003) Isolation and characterization of viruses related to the SARS coronavirus from animals in southern China. 
Hamer SA, Pauvolid-Corrêa A, Zecca IB, Davila E, Auckland LD, Roundy CM, Tang W, Torchetti MK, Killian $M L$, Jenkins-Moore M, et al. (2021) SARS-CoV-2 Infections and Viral Isolations among Serially Tested Cats and Dogs in Households with Infected Owners in Texas, USA. Viruses 13: 938. https://doi.org/10.3390/v13050938

Harvey J (2021) Reflections on the SARS-Covid-2 pandemic after one year: predictable, preventable but inevitable: an ecologist's perspective. Cent Eur Rev Econ Manag 5: 7-22. https://doi.org/10.29015/cerem.912

Hasoksuz M, Alekseev K, Vlasova A, Zhang X, Spiro D, Halpin R, Wang S, Ghedin E, and Saif LJ (2007) Biologic, Antigenic, and Full-Length Genomic Characterization of a Bovine-Like Coronavirus Isolated from a Giraffe. J Virol 81: 4981-4990. https://doi.org/10.1128/JVI.02361-06

Jiang G, Zhang M, and Ma J (2008) Habitat use and separation between red deer Cervus elaphus xanthopygus and roe deer Capreolus pygargus bedfordi in relation to human disturbance in the Wandashan Mountains, northeastern China. Wildl Biol 14: 92-100. https://doi.org/10.2981/09096396(2008)14[92:HUASBR]2.0.C0;2

Kim JH, Jang J-H, Yoon S-W, Noh JY, Ahn M-J, Kim Y, Jeong DG, and Kim HK (2018) Detection of bovine coronavirus in nasal swab of non-captive wild water deer, Korea. Transbound Emerg Dis 65: 627-631. https://doi.org/10.1111/tbed.12847

Kim Y-I, Kim S-G, Kim S-M, Kim E-H, Park S-J, Yu, K-M, Chang J-H, Kim EJ, Lee S, Casel MAB, et al. (2020) Infection and Rapid Transmission of SARS-CoV-2 in Ferrets. Cell Host Microbe 27: 704-709.e2. https://doi.org/10.1016/j.chom.2020.03.023

Klein DR (1992) The Status of Deer in a Changing World Environment. In The Biology of Deer, RD Brown, ed. (New York, NY: Springer), pp 3-12.

Kumar S, Stecher G, Li M, Knyaz C, Tamura K (2018) MEGA X: molecular evolutionary genetics analysis across computing platforms. Mol Biol Evol 35(6):1547-1549. https://doi.org/10.1093/molbev

Lagory KE (1986) Habitat, Group Size, and the Behaviour of White-Tailed Deer. Behaviour 98: 168-179.

Lambert S, Hars J, Réveillaud E, Moyen J-L, Gares H, Rambaud T, Gueneau E, Faure E, Boschiroli M-L, and Richomme C (2016). Host status of wild roe deer in bovine tuberculosis endemic areas. Eur J Wildl Res 63: 15. https://doi.org/10.1007/s10344-016-1071-4

Lau SKP, Woo PCY, Li KSM, Huang Y, Tsoi H-W, Wong BHL, Wong SSY, Leung S-Y, Chan K-H, and Yuen K-Y (2005). Severe acute respiratory syndrome coronavirus-like virus in Chinese horseshoe bats. Proc Natl Acad Sci USA 102: 14040-14045. https://doi.org/10.1073/pnas.0506735102 
Laurent M, Dickie M, Becker M, Serrouya R, and Boutin S (2021) Evaluating the Mechanisms of Landscape Change on White-Tailed Deer Populations. J Wildl Manag 85: 340-353.

https://doi.org/10.1002/jwmg.21979

Lopes LR, de Mattos Cardillo G, and Paiva PB (2020) Molecular evolution and phylogenetic analysis of SARS-CoV-2 and hosts ACE2 protein suggest Malayan pangolin as intermediary host. Braz J Microbiol 51:1593-1599. https://doi.org/10.1007/s42770-020-00321-1

López-Feldman A, Chávez C, Vélez MA, Bejarano H, Chimeli AB, Féres J, Robalino J, Salcedo R, and Viteri, C. (2020). Environmental Impacts and Policy Responses to Covid-19: A View from Latin America. Environ Resour Econ 1-6. https://doi.org/10.1007/s10640-020-00460-x

Majhdi F, Minocha HC, and Kapil S (1997) Isolation and characterization of a coronavirus from elk calves with diarrhea. J Clin Microbiol 35, 2937-2942. https://doi.org/10.1128/jcm.35.11.2937-2942.1997

McAloose D, Laverack M, Wang L, Killian ML, Caserta LC, Yuan F, Mitchell PK, Queen K, Mauldin MR, Cronk BD, et al. (2020) From People to Panthera: Natural SARS-CoV-2 Infection in Tigers and Lions at the Bronx Zoo. MBio 11. https://doi.org/10.1128/mBio.02220-20

McShea WJ (2012) Ecology and management of white-tailed deer in a changing world. Ann N Y. Acad Sci 1249: 45-56. https://doi.org/10.1111/j.1749-6632.2011.06376.x

Medrano C, Boadella M, Barrios H, Cantú A, García Z, de la Fuente J, and Gortazar C (2012) Zoonotic Pathogens among White-Tailed Deer, Northern Mexico, 2004-2009. Emerg Infect Dis. 18: 1372-1374. https://doi.org/10.3201/eid1808.111902

Miller DL, Radi ZA, Baldwin C, and Ingram D (2005). Fatal West Nile virus infection in a white-tailed deer (Odocoileus virginianus). J Wildl Dis 41: 246-249. https://doi.org/10.7589/0090-3558-41.1.246

Nofchissey RA, Deardorff ER, Blevins TM, Anishchenko M, Bosco-Lauth A, Berl E, Lubelczyk C, Mutebi J-P, Brault AC, Ebel GD, et al. (2013) Seroprevalence of Powassan Virus in New England Deer, 1979-2010. Am. J. Trop Med Hyg 88: 1159-1162. https://doi.org/10.4269/ajtmh.12-0586

Palmer MV, Martins M, Falkenberg S, Buckley A, Caserta LC, Mitchell PK, Cassmann ED, Rollins A, Zylich NC, Renshaw RW, et al. (2021) Susceptibility of white-tailed deer (Odocoileus virginianus) to SARS-CoV-2. J Virol 95(11): e00083-21. https://doi.org/10.1128/JVI.00083-21

Petersen BW, Tack DM, Longenberger A, Simeone A, Moll ME, Deasy MP, Blanton JD, and Rupprecht CE (2012) Rabies in Captive Deer, Pennsylvania, USA, 2007-2010. Emerg Infect Dis 18: 138-141. https://doi.org/10.3201/eid1801.111189

Rodríguez F, Oliver JL, Marín A, and Medina JR (1990) The general stochastic model of nucleotide substitution. J Theor Biol 142: 485-501. https://doi.org/10.1016/S0022-5193(05)80104-3 
Ronquist F, Teslenko M, van der Mark P, Ayres DL, Darling A, Höhna S, Larget B, Liu L, Suchard MA, and Huelsenbeck JP (2012) MrBayes 3.2: efficient Bayesian phylogenetic inference and model choice across a large model space. Syst Biol 61: 539-542. https://doi.org/10.1093/sysbio/sys029

do Vale B, Lopes AP, Fontes MC, Silvestre M, Cardoso L, and Coelho AC (2021) Bats, pangolins, minks and other animals - villains or victims of SARS-CoV-2? Vet Res Commun 45: 1-19.

https://doi.org/10.1007/s11259-021-09787-2

Varela D, Trovati R, Guzmán KR, Rossi R, and Duarte JMB (2010) Red brocket deer Mazama americana (Erxleben 1777). In Neotropical Cervidology, pp. 151-159.

Wilson WC, Kim IJ, Trujillo JD, Sunwoo SY, Noronha LE, Urbaniak K, McVey DS, Drolet BS, Morozov I, Faburay B, et al. (2018) Susceptibility of White-Tailed Deer to Rift Valley Fever Virus. Emerg Infect Dis 24: 1717-1719. https://doi.org/10.3201/eid2409.180265

Woo PC, Lau SK, Li KS, Tsang AK, and Yuen K-Y (2012) Genetic relatedness of the novel human group C betacoronavirus to Tylonycteris bat coronavirus HKU4 and Pipistrellus bat coronavirus HKU5. Emerg Microbes Infect 1: 1-5. https://doi.org/10.1038/emi.2012.45

Wynne JW, and Wang L-F (2013) Bats and Viruses: Friend or Foe? PLOS Pathog 9: e1003651. https://doi.org/10.1371/journal.ppat.1003651

Yokoi K, Okazaki H, Inahara K, and Hatama S (2009) Prevalence of eight bovine viruses in sika deer (Cervus nippon yesoensis) in Japan. Vet Rec 165: 754-755. https://doi.org/10.1136/vr.165.25.754

Zhang G, Li B, Yoo D, Qin T, Zhang X, Jia Y, and Cui S. Animal coronaviruses and SARS-CoV-2. Transbound Emerg Dis 68(3)1097-1110. https://doi.org/10.1111/tbed.13791

Zhang XM, Herbst W, Kousoulas KG, and Storz J (1994) Biological and genetic characterization of a hemagglutinating coronavirus isolated from a diarrhoeic child. J Med Virol 44: 152-161. https://doi.org/10.1002/jmv.1890440207

Zhou P, Yang X-L, Wang X-G., Hu B, Zhang L, Zhang W, Si H-R, Zhu Y, Li B, Huang C-L, et al. (2020) A pneumonia outbreak associated with a new coronavirus of probable bat origin. Nature 579: 270-273. https://doi.org/10.1038/s41586-020-2012-7

\section{Tables}


General cervid informations

\begin{tabular}{|c|c|c|c|c|c|}
\hline Subfamily & Species & Popular name & $\begin{array}{l}\text { Red } \\
\text { list }\end{array}$ & $\begin{array}{l}\text { Population } \\
\text { trend }\end{array}$ & Geographic distribution \\
\hline \multirow[t]{16}{*}{ Cervinae } & Axis axis & Chital & LC & Unknown & Asia \\
\hline & Axis porcinus & Hog deer & EN & Decreasing & Asia \\
\hline & Axis kuhlii & Bawean Deer & $\mathrm{CR}$ & Decreasing & Asia (Indonesia) \\
\hline & $\begin{array}{l}\text { Cervus } \\
\text { canadensis }\end{array}$ & Wapiti & LC & Increasing & $\begin{array}{l}\text { Asia and North } \\
\text { America }\end{array}$ \\
\hline & Cervus elaphus & Red deer & LC & Increasing & $\begin{array}{l}\text { Europe, Asia (Russia) } \\
\text { and Middle East }\end{array}$ \\
\hline & Cervus nippon & Sika deer & LC & Increasing & Asia \\
\hline & Dama dama & Dama deer & LC & Unknown & Europe \\
\hline & $\begin{array}{l}\text { Dama } \\
\text { mesopotamica }\end{array}$ & $\begin{array}{l}\text { Persian Fallow } \\
\text { Deer }\end{array}$ & EN & Increasing & Asia (Iran) \\
\hline & $\begin{array}{l}\text { Elaphurus } \\
\text { davidianus }\end{array}$ & $\begin{array}{l}\text { Père David's } \\
\text { Deer }\end{array}$ & EW & Unespecified & \\
\hline & $\begin{array}{l}\text { Przewalskium } \\
\text { albirostris }\end{array}$ & $\begin{array}{l}\text { White-lipped } \\
\text { Deer }\end{array}$ & VU & Unknown & Asia (China) \\
\hline & $\begin{array}{l}\text { Rucervus } \\
\text { duvaucelii }\end{array}$ & Barasingha & VU & Decreasing & Asia (India and Nepal) \\
\hline & Rucervus eldii & Eld's Deer & EN & Decreasing & Asia \\
\hline & Rusa alfredi & $\begin{array}{l}\text { Philippine } \\
\text { Spotted Deer }\end{array}$ & EN & Decreasing & Asia (Philippines) \\
\hline & Rusa marianna & Philippine Deer & VU & Decreasing & Asia (Philippines) \\
\hline & $\begin{array}{l}\text { Rusa } \\
\text { timorensis }\end{array}$ & Javan Deer & VU & Decreasing & Asia (Indonesia) \\
\hline & Rusa unicolor & Sambar & VU & Decreasing & Asia \\
\hline Hydropotinae & $\begin{array}{l}\text { Hydropotes } \\
\text { inermi }\end{array}$ & Water Deer & VU & Decreasing & Asia (China and Korea) \\
\hline \multirow[t]{4}{*}{ Muntiacinae } & $\begin{array}{l}\text { Elaphodus } \\
\text { cephalophus }\end{array}$ & Tufted Deer & NT & Decreasing & Asia (China) \\
\hline & $\begin{array}{l}\text { Muntiacus } \\
\text { atherodes }\end{array}$ & $\begin{array}{l}\text { Bornean Yellow } \\
\text { Muntjac }\end{array}$ & NT & Decreasing & Asia (Malasya) \\
\hline & $\begin{array}{l}\text { Muntiacus } \\
\text { feae }\end{array}$ & Fea's Muntjac & DD & Unknown & $\begin{array}{l}\text { Asia (Myamar and } \\
\text { Thailand) }\end{array}$ \\
\hline & Muntiacus & Gongshan & DD & Decreasing & Asia (China and \\
\hline
\end{tabular}




\begin{tabular}{|c|c|c|c|c|c|}
\hline & gongshanensis & Muntjac & & & Myanmar) \\
\hline & $\begin{array}{l}\text { Muntiacus } \\
\text { muntjak }\end{array}$ & $\begin{array}{l}\text { Southern Red } \\
\text { Muntjac }\end{array}$ & LC & Decreasing & Asia \\
\hline & $\begin{array}{l}\text { Muntiacus } \\
\text { putaoensis }\end{array}$ & Leaf Muntjac & DD & Decreasing & $\begin{array}{l}\text { Asia (India and } \\
\text { Myanmar) }\end{array}$ \\
\hline & $\begin{array}{l}\text { Muntiacus } \\
\text { reevesi }\end{array}$ & $\begin{array}{l}\text { Reeves' } \\
\text { Muntjac }\end{array}$ & LC & Decreasing & Asia (China) \\
\hline & $\begin{array}{l}\text { Muntiacus } \\
\text { rooseveltorum }\end{array}$ & $\begin{array}{l}\text { Roosevelts' } \\
\text { Muntjac }\end{array}$ & DD & Decreasing & Asia (Laos) \\
\hline & $\begin{array}{l}\text { Muntiacus } \\
\text { vaginalis }\end{array}$ & $\begin{array}{l}\text { Northern Red } \\
\text { Muntjac }\end{array}$ & LC & Decreasing & Asia \\
\hline & $\begin{array}{l}\text { Muntiacus } \\
\text { vuquangensis }\end{array}$ & $\begin{array}{l}\text { Large-antlered } \\
\text { Muntjac }\end{array}$ & CR & Decreasing & Asia \\
\hline Odocoileinae & Alces alces & Moose & LC & Increasing & $\begin{array}{l}\text { Asia, Europe and North } \\
\text { America }\end{array}$ \\
\hline & $\begin{array}{l}\text { Blastocerus } \\
\text { dichotomus }\end{array}$ & Marsh Deer & VU & Decreasing & South America \\
\hline & $\begin{array}{l}\text { Capreolus } \\
\text { capreolus }\end{array}$ & $\begin{array}{l}\text { European Roe } \\
\text { Deer }\end{array}$ & LC & Increasing & $\begin{array}{l}\text { Europe and Middle } \\
\text { East }\end{array}$ \\
\hline & $\begin{array}{l}\text { Capreolus } \\
\text { pygargus }\end{array}$ & $\begin{array}{l}\text { Siberian Roe } \\
\text { Deer }\end{array}$ & LC & Decreasing & Asia \\
\hline & $\begin{array}{l}\text { Hippocamelus } \\
\text { antisensis }\end{array}$ & Taruca & VU & Decreasing & South America \\
\hline & $\begin{array}{l}\text { Hippocamelus } \\
\text { bisulcus }\end{array}$ & $\begin{array}{l}\text { Patagonian } \\
\text { Huemul }\end{array}$ & EN & Decreasing & South America \\
\hline & $\begin{array}{l}\text { Mazama } \\
\text { americana }\end{array}$ & Red brocket & DD & Unknown & South America \\
\hline & $\begin{array}{l}\text { Mazama } \\
\text { bororo }\end{array}$ & $\begin{array}{l}\text { Small Red } \\
\text { Brocket }\end{array}$ & VU & Decreasing & South America (Brazil) \\
\hline & $\begin{array}{l}\text { Mazama } \\
\text { chunyi }\end{array}$ & $\begin{array}{l}\text { Peruvian Dwarf } \\
\text { Brocket }\end{array}$ & VU & Decreasing & $\begin{array}{l}\text { South America (Bolivia } \\
\text { and Peru) }\end{array}$ \\
\hline & $\begin{array}{l}\text { Mazama } \\
\text { gouazoubira }\end{array}$ & Gray brocket & LC & Decreasing & South America \\
\hline & Mazama nana & $\begin{array}{l}\text { Brazilian Dwarf } \\
\text { Brocket }\end{array}$ & VU & Unknown & South America \\
\hline & $\begin{array}{l}\text { Mazama } \\
\text { nemorivaga }\end{array}$ & $\begin{array}{l}\text { Amazonian } \\
\text { Brown Brocket }\end{array}$ & LC & Decreasing & South America \\
\hline & $\begin{array}{l}\text { Mazama } \\
\text { pandora }\end{array}$ & $\begin{array}{l}\text { Yucatan Brown } \\
\text { Brocket }\end{array}$ & VU & Decreasing & $\begin{array}{l}\text { Central America and } \\
\text { North America } \\
\text { (Mexico) }\end{array}$ \\
\hline
\end{tabular}




\begin{tabular}{|c|c|c|c|c|}
\hline Mazama rufina & $\begin{array}{l}\text { Dwarf Red } \\
\text { Brocket }\end{array}$ & VU & Decreasing & South America \\
\hline $\begin{array}{l}\text { Mazama } \\
\text { temama }\end{array}$ & $\begin{array}{l}\text { Central } \\
\text { American Red } \\
\text { Brocket }\end{array}$ & $\mathrm{DD}$ & Decreasing & $\begin{array}{l}\text { Central America and } \\
\text { North America } \\
\text { (Mexico) }\end{array}$ \\
\hline $\begin{array}{l}\text { Odocoileus } \\
\text { hemionus }\end{array}$ & Mule deer & LC & Stable & North America \\
\hline $\begin{array}{l}\text { Odocoileus } \\
\text { virginianus }\end{array}$ & $\begin{array}{l}\text { White tailed } \\
\text { deer }\end{array}$ & LC & Stable & America \\
\hline $\begin{array}{l}\text { Ozotoceros } \\
\text { bezoarticus }\end{array}$ & Pampas Deer & NT & Decreasing & South America \\
\hline $\begin{array}{l}\text { Pudu } \\
\text { mephistophiles }\end{array}$ & Northern Pudu & $\mathrm{DD}$ & Decreasing & South America \\
\hline Pudu puda & Southern Pudu & NT & Decreasing & $\begin{array}{l}\text { South America } \\
\text { (Argentina and Chile) }\end{array}$ \\
\hline $\begin{array}{l}\text { Rangifer } \\
\text { tarandus }\end{array}$ & Reindeer & VU & Decreasing & $\begin{array}{l}\text { Europe, Asia (Russia) } \\
\text { and North America } \\
\text { (Canada) }\end{array}$ \\
\hline
\end{tabular}

Table 1 - Classification of cervids was based on NCBI Taxonomy Database (https://www.ncbi.nlm.nih.gov/taxonomy/). Geographic, populational and extinction risk data were extracted from the International Union for Conservation of Nature's (IUCN) Red List of Threatened Species. The IUCN Red List includes categories ordered in decreasing risk of collapse: extinct in the wild $(E W)$, critically endangered (CR), endangered (EN), vulnerable (VU), near threatened (NT), least concern (LC). The category data deficient (DD) does not indicate a level of risk.

\section{Figures}




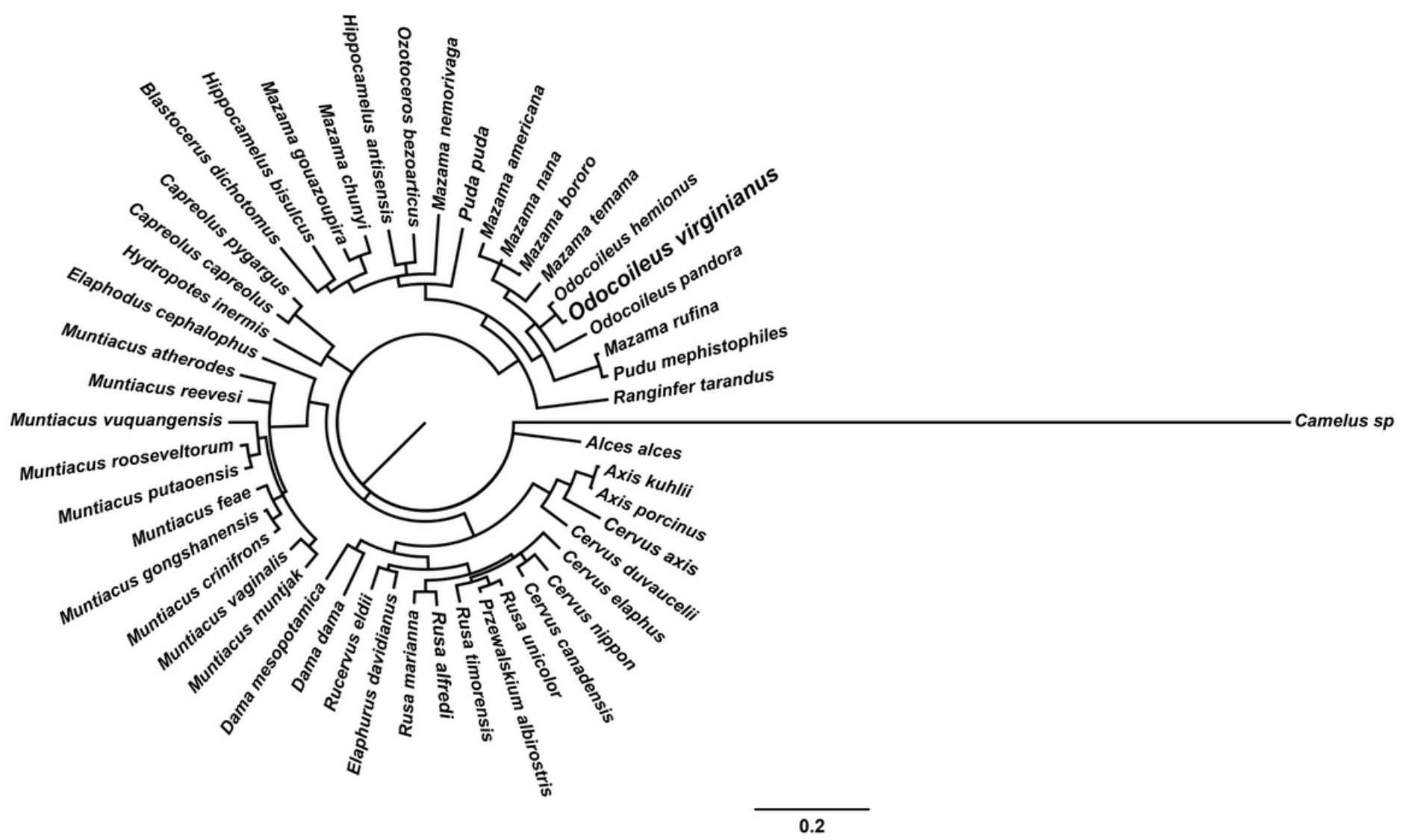

\section{Figure 1}

Bayesian phylogenetic inference based on $(n=49)$ mitochondrial cytochrome b (cyt b) nucleotide sequences of cervids. Camel was included as outgroup. White-tailed deer (Odocoileus virginianus), susceptible host to SARS-CoV-2, are highlighted in the tree, nested with gender Odocoileus and gender Mazama. All sequences were obtained from NCBI Genbank database (http://ncbi.nlm.nih.gov/Genbank). To infer phylogenetic Bayesian tree, substitution models selection was based on the Akaike Information Criterion (AIC) and Bayesian Information Criterion (BIC), using MEGA X software (DNA model selection). General time-reversible (GTR) model with gamma distribution and proportion of invariant sites $(\mathrm{GTR}+\mathrm{G}+\mathrm{I})$ was selected according to the best perfom. The tree is drawn to scale, with branch lengths measured in the number of substitutions per site. Phylogenetic analyses were conducted in MrBayes and the trees were formatted with the FigTree v1.3.1 software (http://tree.bio.ed.ac.uk/software/figtree/). 